but in practice this treatment must still be regarded as debatable. ${ }^{22}{ }^{23}$ Whether increased intakes of vitamin $D$ will prevent skeletal rarefaction in old age has yet to be determined, but an intake of $100 \mathrm{IU}$ a day is certainly desirable. ${ }^{24}$ When the clinical syndrome has developed, with attacks of acute pain associated with spontaneous vertebral collapse in the dorsolumbar region, immobilization in bed or with a spinal brace is harmful. An elasticized dorsolumbar corset can relieve pain; graduated spinal exercises can improve muscle power; and balancing exercises can reduce the risk of falls leading to fracture.

1 Albright, F., Bloomberg, E., and Smith, P. H., Transactions of the Association of American Physicians, 1940, 55, 298.

Broman, G. E., Trotter, M., and Peterson, R. R., American fournal of Physical Anthropology, 1958, 16, 197.

3 Caldwell, R. A., and Collins, D. H., fournal of Bone and Foint Surgery, 1961, 43B, 346 .

- Garn, S. M., Rohmann, C. G., and Wagner, B., Federation Proceedings,

1967, 26, 1729. Springfield, Illinois, Thomas, 1970.

Newton-John, H. F., and Morgan, D. B., Lancet, 1968, 1, 232.

Urist, M. R., Gurvery, M. S., and Fareed, D. O., in Osteoporosis, ed. U. Barzel. New York, Grune and Stratton, 1970.

8 Nordin, B. E. C., Young, M. M., Bentley, B., Ormondroyd, P., and Sykes, J., Clinical Radiology, 1968, 19, 459 .

- Nordin, B. E. C., Lancet, 1961, 1, 1011 .

- Heaney, R. P., American fournal of Medicine, 1965, 39, 877.

Whedon, G. D., in Osteoporosis, ed. U. Barzel. New York, Grune and Stratton, 1970 .

12 Bullamore, J. R., Gallagher, J. C., Wilkinson, R., Nordin, B. E. C., and Marshall, D. H., Lancet, 1970, 2, 535 .

13 Anderson, I., Campbell, A. E. R., Dunn, A., and Runciman, J. B. M., Scottish Medical fournal, 1966, 11, 429.

${ }^{4}$ Exton-Smith, A. N., Hodkinson, H. M., and Stanton, B. R., Lancet, 1966, 2, 999.

15 Smith, R. W., Rizek, J., Frame, B., and Mansour, J., American fournal of Clinical Nutrition, 1964, 14, 98.

6 Exton-Smith, A. N., Millard, P. H., Payne, P. R., and Wheeler, E. F., Lancet, 1969, 2, 1154.

17 Adams, P., Davies, G. T., and Sweetnam, P., Quarterly Fournal of Medicine, 1970, 39, 601 .

18 Dent, C. E., and Watson, L., Postgraduate Medical fournal, 1966, 42,

Sorenson, J. A., and Cameron, J. R., Fournal of Bone and Foint Surgery, 1967, 49A, 481.

20 Davis, M. E., Lanzl, L. H., and Strandjord, N. M., Fournal of the American Medical Association, 1966, 196, 219.

21 Meema, H., and Meema, S., Canadian Medical Association fournal, $1968,99,248$.

22 British Medical fournal, 1967, 2, 295.

23 British Medical fournal 1669 1, 621.

4 Department of Health and Social Security, Recommended Nutrient Intakes for the United Kingdom. London, H.M.S.O., 1969.

\section{Schatzki's Ring}

Lower oesophageal ring is an unusual condition which presents clinically as occasional episodes of aphagia, often after the patient attempts to swallow an unusually large unchewed bolus. ${ }^{12}$ This feature has earned it the title of the steakhouse syndrome. Over some years the patient may develop persistent and progressive dysphagia, first for solids and then for semisolids and liquids.

The oesophageal obstruction is caused by a concentric narrowing of the lumen just above the diaphragm. The narrowing may slowly progress, but dysphagia rarely develops until the lumen is less than $20 \mathrm{~mm} .^{1}$ The narrowing is caused by submucosal fibrosis. The overlying mucosa in intact and the underlying muscle is normal. A hiatus hernia is usually present. A study of the pathology of 14 resected specimens ${ }^{3}$ showed the mucosa above the ring to be squamous-celled and that below it to be columnar-celled. Fibrosis and chronic inflammatory changes were present in the submucosa. It has been suggested that the ring develops as kissing ulcers (secondary to reflux oesophagitis) become adherent and draw out the mucosa. ${ }^{4}$
In some patients the ring is possibly congenital, for the history may date back to early life and other congenital abnormalities such as epiphrenic diverticulum may be associated with it. A mid-oesophageal ring has been reported in a child of 3 weeks. ${ }^{5}$ In a report of 7 patients there was no hiatus hernia in 4 and the ring was proximal to the usual site; in one it was 4 inches above the hiatus. ${ }^{6}$

Barium studies are diagnostic. The lesion shows as a constant, symmetrical, thin diaphragm projecting into the lumen at right angles to the long axis of the oesophagus. ${ }^{1}$ It is best seen with patient lying horizontal, face down, and slightly turned to the right. The oesophagus is then distended by asking the patient to take a deep breath or perform a Valsalva manoeuvre just before the bolus arrives at the lower end of the oesophagus. If a barium pill is swallowed a downward bowing of the web is seen as peristalsis forces the bolus through the narrowed lumen. The lesion may be overlooked at oesophagoscopy unless the narrowing is considerable or an oesophagoscope of large diameter is used.

Treatment is not required unless the ring causes troublesome dysphagia. Rings discovered as a chance finding on barium meal may remain unchanged and completely asymptomatic for years. The aim of any treatment is to increase the size of the lumen and prevent recurrence of the narrowing. A review of the treatment in 59 patients discusses the results of treatment. ${ }^{7}$ In some patients endoscopic dilation produces a satisfactory result. If gastro-oesophageal reflux is present, then repair of the hiatus hernia with digital rupture of the mucosal web of the ring either through the invaginated stomach wall or through a small incision in stomach wall has been used with success. More recently formal excision of the web through gastrotomy or oesophagotomy has been advocated. The mucosal web is completely excised and the edges of the mucosa resutured; the muscular wall is not resected. Repair of the hiatus hernia is added if necessary. There is no indication for oesophageal resection if the diagnosis is made.

\footnotetext{
Schatzki, R., and Gary, J. E., American fournal of Roentgenology, 1953 70, 911 .

Inglefinger, F. J., and Kramer, P., Gastroenterology, 1953, 23, 419.

Postlethwait, R. W., and Musser, A. W., Surgery, Gynecology and Obstetrics, $1965,120,571$

1 Allison, P. R., Annals of Surgery, 1967, 165, 795.

S Mark, J. B., and Goldenberg, I. S., Fournal of Thoracic and Cardiovascular Surgery, 1964, 48, 506.

- Gerami, S., and Cole, F. H., Annals of Thoracic Surgery, 1970, 10, 223.

Postlethwait, R. W., and Sealy, W. C., Annals of Surgery, 1967, 165, 786
}

\section{Future of Queen Charlotte's Hospital}

The future of Queen Charlotte's Hospital in West London is being discussed in official circles and has recently been ventilated in the columns of The Times. ${ }^{1}$ The suggestion that this internationally known hospital might close its doors at least to maternity cases is being considered and the reasons for it are extremely complex.

Over recent years the pressure on maternity beds in the London area as a whole has fallen. The population of London itself is falling, and so (at present) is the national birth rate. The length of stay of women in maternity hospitals has been progressively reduced, thanks largely to better obstetric care and a healthier population, and thus fewer complications affect mothers and their babies. The introduction of shortstay arrangements by which mothers remain in hospital 48 